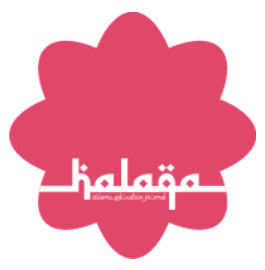

\title{
Application of Ash-Shafi'i Method in Learning Tahsin Al Qur'an in Mushallah Ahsanul Qolbu
}

\section{Penerapan metode Asy-Syafi'i Dalam Pembelajaran Tahsin Al Qur'an Di Mushallah Ahsanul Qolbu}

\author{
Mappanyompa $^{1 *}$, Hidayatussaliki ${ }^{2}$ \\ Fakultas Penddidikan Agama Islam, Universitas Muhammadiyah Mataram, Indonesia
}

The purpose of this research is: Analyzing and describing the impact of the application of ash-Shafi'i method in the learning of Tahsin Al-Quran in Mushallah Ahsanul Qolbu Housing Griya Sehati Terongtawah by making students more independent, more active and not boring in the learning process, the methods given in this book use the pattern of self-reliance and continuous exercises. The type of research that the authors conducted is field research directly from the research site using observations, interviews, and documentation which is then analyzed using interactive analysis techniques of Model Miles and Huberman which include data reduction, presenting data, to verifying and concluding data. The results of this study is the application of ash-Shafi'i method conducted by teachers in the learning of the Qur'ean has a good impact on the ability to read the Qur'an"an learners, learning planning, and evaluation of learning is inseparable from the standard provisions of the method of Ash-Shafi'i namely opening, apersepsi, planting concepts, understanding concepts, exercises / skills independence, evaluation and closing.

myompakaltim@gmail.com

Received: 8 Juni 2021 Accepted: 28 Juni 2021

Published:8 Juli 2021

Citation:

Mappanyompa, Hidayatussaliki (2021) Application of Ash-Shafi'i method in learning Tahsin Al Qur'an in Mushallah Ahsanul Qolbu. Halaqa: Islamic Education Journal.

doi: 10.21070/ halaqa.v5vi2i.1436
Keywords: Ash-Shafi'i Method, Tahsin, Qur'an Learning, Learning To Recite

Tujuan Penelitian ini adalah: Menganalisis dan mendeskripsikan dampak penerapan metode Asy-Syafi'i dalam pembelajaran Tahsin Al-Quran di Mushallah Ahsanul Qolbu Perumahan Griya Sehati Terongtawah dengan menjadikan peserta didik lebih mandiri, lebih aktif dan tidak membosankan didalam proses pembelajaran, metode yang diberikan didalam buku ini menggunakan pola latihan-latihan kemandirian dan berkesinambungan. Jenis Penelitian yang penulis lakukan adalah penelitian lapangan (field research) langsung dari lokasi penelitian dengan menggunakan observasi, wawancara, dan dokumentasi yang kemudian dianalisis dengan menggunakan teknik analisis interaktif Model Miles dan Huberman yang meliputi reduksi data, menyajikan data, hingga memverifikasi dan menyimpulkan data. Adapun hasil penelitian ini yakni penerapan metode Asy-Syafi'i yang dilakukan guru dalam pembelajaran Al-Quran sangat berdampak baik terhadap kemampuan membaca Al-Quran peserta didik, perencanaan pembelajaran, dan evaluasi pembelajaran tidak terlepas dari ketentuan baku metode Asy-Syafi'i yaitu pembukaan, apersepsi, penanaman konsep, pemahaman konsep, latihan/keterampilan kemandirian, evaluasi dan penutup. 


\section{PENDAHULUAN}

Perkembangan dan kemajuan berpikir manusia senantiasa disertai oleh wahyu yang sesuai dan dapat memecahkan problem-problem yang dihadapi oleh suatu kaum setiap Nabi dan Rasul pada saat itu, sampai perkembangan itu mengalami kematangannya. Allah menghendaki agar risalah Nabi Muhammad saw. muncul di dunia ini. Diutuslah beliau di saat manusia sedang mengalami kekosongan para Nabi dan Rasul, untuk menyempurnakan bangunan utusan-utusan pendahulunya dengan syari'atnya yang universal dan abadi serta dengan Kitab yang diturunkan kepadanya, yaitu AlQur'anul Karim. Ishaq \& Nawawi (2017) Al-Qur'an adalah sumber utama ajaran Islam dan merupakan pedoman hidup bagi semua muslim. Al-Qur'an bukan sekedar memuat petunjuk tentang hubungan manusia dengan Tuhannya, tetapi juga mengatur hubungan manusia dengan sesamanya, bahkan hubungan manusia dengan alam. Selain itu, Al-Qur'an juga memberikan petunjuk dalam persoalan-persoalan akidah, syari'ah, dan akhlak, dengan jalan meletakkan dasar-dasar prinsipil mengenai persoalan-persoalan tersebut; dan Allah SWT menugaskan Rasul saw untuk memberikan keterangan yang lengkap mengenai dasar-dasar itu. Shihab (2011) Sementara itu di dalam Al-Qur'an ditegaskan bahwasannya Al-Qur'an juga mengintroduksikan dirinya sebagai pemberi petunjuk kepada jalan yang lebih lurus. Petunjuk-petunjuknya bertujuan memberi kesejahteraan dan kebahagiaan bagi manusia, baik secara pribadi maupun kelompok, dan karena itu ditemukan petunjuk-petunjuk bagi manusia dalam kedua bentuk tersebut. Alamsyah (2015).

Membaca Al-Quran adalah kegiatan mendidik, mengajar, membimbing, dan melatih peserta didik belajar dalam peningkatan kompetensi. seperti yang disabdakan oleh Rosulullah: "Sebaik-baik kamu adalah orang yang belajar Al-Qur'an dan mengajarkannya" (HR. Bukhari). Dinyatakan juga dalam hadis yang lain: "Belajarlah Al-Qur'an lalu bacalah. Sesungguhnya perumpamaan Al-qur'an bagi orang yang belajar, membaca, dan mengamalkannya, bagaikan wadah yang dipenuhi minyak kasturi yang semerbak baunya disetiap tempat". (HR. Tirmidzi). Purba (2019) Adapun dalam firman Allah, Artinya: "Bacalah dengan (menyebut) nama Tuhanmu yang Menciptakan, Dia Telah menciptakan manusia dari segumpal darah. Bacalah, dan Tuhanmulah yang Maha pemurah, Yang mengajar (manusia) dengan perantaran kalamDia mengajar kepada manusia apa yang tidak diketahuinya." (Q.S. Al-Al alaq ayat 1-5) Pembelajaran Al-Quran yang optimal akan melahirkan generasi Qur'ani yang mampu memakmurkan bumi dengan Al-Qur'an dan menyelamatkan peradaban dunia dimasa mendatang. Syarat mutlak untuk memunculkan generasi Qur'ani adalah adanya pemahaman terhadap Al-Qur'an yang diawali dengan mampu membaca Al-Qur'an dengan baik dan benar sesuai dengan kaidah yang ditentukan. Mubarak (2013) Sabda Rasulullah Shallalahu 'alaihi wasallam: "Orang yang membaca al-Qur'an, lagi pula ia mahir, kelak mendapat tempat di dalam surga bersama dengan rasul-rasul yang mulia lagi baik, dan orang yang membaca al-Qur'an, tetapi tidak mahir. Membacanya tertegun-tegun dan tampak agak berat lidahnya (belum lancar), dia akan mendapatkan dua kali lipat pahala." (HR. Bukhari Muslim). Shihab (2011)
Mempelajari al-Qur'an juga tidak lepas dari pengaruh keluarga, karena keluarga merupakan pengaruh pertama untuk memperoleh pendidikan di awal kepribadian anak di kemudian hari. Untuk menunjang keberhasilan pengajaran alQur'an tidak cukup diberikan di sekolah saja, oleh karena itu pihak orang tua sangat berperan dalam pendidikan. Mappanyompa \& Mustapa (2017) Orang tua atau dan masyarakat diharapkan dapat membantu Guru Pendidikan Agama Islam agar terjadi sinkronisasi antara pendidikan Agama Islam di sekolah, keluarga dan masyarakat, karena pembelajaran al-Qur'an sebagai suatu proses pengembangan potensi kreatifitas peserta didik yang bertujuan untuk mewujudkan manusia yang bertaqwa kepada Allah, dan bersifat cerdas, berbudi pekerti luhur, mandiri dan bertanggungjawab terhadap dirinya, serta agama. Dengan demikian seorang pendidik harus meningkatkan kualitas dalam pembelajaran agar potensi yang dimiliki peserta didik bisa berkembang dengan optimal. Satria et al. (2015)

Kegiatan belajar mengajar merupakan inti dari pelaksanaan kurikulum, baik buruknya pendidikan atau mutu lulusan dipengaruhi oleh mutu kegiatan belajar mengajarnya. Bila mutu lulusannya bagus, dapat diprediksi bahwa mutu kegiatan belajar mengajarnya juga bagus atau sebaliknya, bila mutu belajar mengajarnya bagus, maka mutu lulusannya juga akan bagus. Proses pembelajaran al-Qur'an dengan menggunakan metode yang tepat akan mempermudah peserta untuk bisa membaca al-Qur'an dengan cepat. Salah satu penentu dalam kegiatan belajar mengajar a1-Qur'an adalah metode. Ishaq \& Nawawi (2017)

Faktor Masalah dalam Pembelajaran Al-Qur'an diantaranya: a). Model pembelajaran yang diterapkan pada pembelajaran Al-Qur'an, kurang menarik minat peserta didik yakni masih berupa ceramah, b). Bervariasinya latar belakang pendidikan peserta didik baik yang pernah mondok dan umu, c). Pembelajaran Al-Qur'an terkadang masih bersifat teacher center (berpusat pada guru), bukan student center (berpusat pada peserta didik), sehingga belum efektif meningkatkan kemampuan Peserta didik dalam membaca Al-Qur'an, d). Media belajar yang dimiliki pendidik (guru) kurang menarik untuk menumbuhkan minat Peserta didik dalam melaksanakan pembelajaran dan terkadang sedikit sekali menggunakan pendekatan TIK (Teknologi Informasi dan Komunikasi), e). Kurangnya dukungan dari lingkungan untuk selalu berinteraksi dengan Al-Qur'an. Purba (2019) Salah satu panduan dalam pembelajaran membaca Al Qur'an adalah metode Asy-syafi'i. dengan penggunaan sistem multimedia pada pembelajaran membaca Al Qur'an metode Asy-syafi'i diharapkan dapat mempermudah dan memberikan kenyamanan bagi pengguna dalam mempelajari bacaan AlQur'an. Metode Asy-Syafi'i merupakan cara yang memudahkan bagi seseorang dalam mempelajari Al-Qur'an.

Metode asy-syafi'I merupakan rintisaan dari buku Ilmu Tajwid Praktis yang dikembangkan oleh Ustadz Abu Ya'la Kurnaedi Dkk, buku ini berupa diktat panduan praktis belajar membaca Al-Qur-an dan ilmu tajwid yang diterapkan di mahad Imam asy-Syafii. Diktat itu sengaja disusun dengan pendekatan praktik, metode yang mudah, dan waktu yang singkat. Setelah melalui uji coba dan pelatihan selama dua tahun, yang dalam periode tersebut dilakukan evaluasi serta perbaikan disegala sisi baik pada sisi setingan, metode pembe- 
lajaran, bahasa penjabaran maupun sisi pilihan ragam tulisan, metode yang lebih menarik dan mudah untuk dipelajari dan dipahami. Mengingat cikal bakal buku ini merupakan diktat yang diujicobakan dan dipraktikkan di mahad Imam asySyafi'i, maka nama buku ini dengan metode Asy-Syafi'i. Dengan harapan umat Islam yang mempelajari dan mengamalkan buku ini dapat membaca Al-Qur-an dengan baik dan benar sebagaimana dicontohkan oleh Rasulullah, serta menjadi sebaik-baik umat Islam.

Berangkat dari permasalahan diatas, peneliti akan meneliti dalam pembelajaran tahsin al-Qur'an dengan metode asy-Syafi'i, Yaitu sebuah metode yang mudah, praktis dan tidak membosankan dengan tempo waktu yang sangat singkat dan didesain khusus untuk anak yang belum bisa membaca alQur'an dengan baik dan benar. Hal itulah yang memotivasi peneliti untuk membuat penelitian dengan judul: Penggunaan Metode Asy-Syafi'i Dalam Pembelajaran Tahsin Al Quran Di Mushallah Ahsanul Qolbu Perumahan Griya Sehati Terongtawah Kec. Labuapi.

\section{METODE PENELITIAN}

\section{Tahap Penelitian}

Tahapan metodologi penelitian Penerapan Metode AsySyafi'i Dalam Pembelajaran Tahsin Al Quran dijelaskan secara umum sebagai berikut:

\section{[Figure 1 about here.]}

a) Survey Literatur, tahap ini adalah melakukan pengumpulan bahan literatur dan informasi berkaitan dengan judul penelitian; b) Identifikasi Masalah, melakukan identifikasi tentang masalah apa yang akan dibahas berkaitan dengan Metode Asy-Syafi'i dalam Pembelajaran Tahsin Al Quran berdasarkan literatur dan informasi yang telah diperoleh; c) Studi Pustaka, mempelajari literatur yang akan digunakan sebagai kajian teori dalam penelitian ini; d) Menentukan masalah, dan sampel, menentukan masalah mengenai penerapan metode Asy-Syafi'i dalam pembelajaran Tahsin Al- Quran di Mushallah Ahsanul Qolbu Perumahan Griya Sehati Terongtawah Kec. Labuapi. Kemudian menentukan data-data seperti apa yang dibutuhkan berdasarkan populasi, sampel dan cara pengambilan sampel. Kemudian menentukan subjek penelitian dan respondennya; e) Menentukan pertanyaan, tahap ini adalah membuat pertanyaan-pertanyaan berkaitan penerapan metode AsySyafi'i dalam pembelajaran Tahsin Al- Quran di Mushallah Ahsanul Qolbu Perumahan Griya Sehati Terongtawah Kec. Labuapi. f) Observasi Lapangan dan Perijinan, melakukan pencarian sumber data dan perijinan kepada pihak-pihak yang berkompeten dalam penelitian ini; g) Mengumpulkan Data, wawancara kepada responden. Hal ini dilakukan bersamaan dengan observasi dan perijinan untuk menghemat waktu, biaya dan tenaga; h) Pengolahan Data, pengolahan data terdiri dari pemberian kode pada data yang ditemukan melalui hasil wawancara berdasarkan pertanyaan yang di kemukakan pada responden; i) Analisa Data, menganalisa hasil pengolahan data berdasarkan hasil penelitian dan teori yang ada; j) Menarik Kesimpulan, kesimpulan diambil berdasarkan analisa data dan diperiksa apakah sesuai dengan maksud dan tujuan penelitian.

\section{Lokasi Penelitian}

Penelitian ini mengambil lokasi di Mushallah Ahsanul Qolbu Perumahan Griya Sehati Terongtawah Kec. Labuapi. Dipilihnya sebagai lokasi penelitian disebabkan karena beberapa alasan yaitu; pertama, peneliti mengasumsi semangat peserta didik didalam belajar al-Qur'an sangat tinggi dibandingkan dengan tempat-tempat pembelajaran alQur'an yang lain. Kedua, belum pernah ada peneliti yang melakukan penelitian di Mushallah Ahsanul Qolbu Perumahan Griya Sehati Terongtawah Kec. Labuapi, yang secara spesifik berkaitan tentang metode pembelajaran alQur'an dengan metode Asy-Syafi'i. Ketiga, jangkauan peneliti dalam proses penelitian mudah dan bisa dijangkau karena lokasi penelitian masih berada di satu kota yaitu wilayah kota mataram.

\section{Variabel Penelitian}

Variabel penelitian adalah suatu atribut atau sifat atau nilai dari orang, obyek atau kegiatan yang mempunyai variasi tertentu yang ditetapkan oleh peneliti untuk dipelajari dan ditarik kesimpulannya (Nazir, 2014). Dalam penelitian ini menggunakan dua variabel, yaitu variabel bebas dan variabel terikat. Variabel bebas (independent variable) atau variabel X adalah variabel yang dipandang sebagai penyebab munculnya variabel terikat yang diduga sebagai akibatnya. Sedangkan variabel terikat (dependent variable) atau variabel $\mathrm{Y}$ adalah variabel (akibat) yang dipradugakan, yang bervariasi mengikuti perubahan dari variabel-variabel bebas. Umumnya merupakan kondisi yang ingin kita ungkapkan dan jelaskan. Sugiyono (2017) a) Variabel Bebas (Independent): Penerapan Metode Asy-Syafi'i; b) Variabel Tergantung (Dependent): Pembelajaran Tahsin Al Qur'an

\section{Pendekatan dan Jenis Penelitian}

Pendekatan adalah perlakuan terhadap objek, sebagai sudut pandang etik, atau sebaliknya bagaimana seharusnya memperlakukan objek, sebagai sudut pandang emik. Maka pendekatan yang digunakan dalam penelitian ini adalah pendekatan kualitatif. Salah satu karakteristik pendekatan kualitatif adalah deskriptif. Menurut Prastowo (2011), penelitian deskriptif adalah penelitian yang mencari fakta dengan interpretasi yang tepat. Nazir (2014) Jenis penelitian yang digunakan dalam penelitian ini adalah penelitian lapangan atau (field research) kualitatif. Alasan utama peneliti menggunakan pendekatan kualitatif dalam penelitian ini adalah karena metode ini lebih fleksibel dan bisa menyesuaikan diri dengan ragam kenyataan di lapangan.

\section{Rancangan Penelitian}

Penelitian kualitatif merupakan penelitian interpretatif, yang di dalamnya peneliti terlibat dalam pengalaman yang berkelanjutan dan terus menerus dengan para partisipan. Keterlibatan ini dalam proses penelitian kualitatif akan memunculkan serangkaian isu-isu strategis, etis dan personal. Creswell (2010) Kehadiran peneliti dalam penelitian kualitatif adalah sebagai "otak", "mesin" dan "instrumen" utama penelitian yang dapat memahami makna interaksi antar-manusia, membaca gerak muka, menyelami perasaan dan nilai yang terkandung dalam ucapan atau perbuatan responden. Peneliti hadir dengan melalui beberapa tahapan 
yaitu exploration, cooperation dan participation. Sugiyono (2017) Tahapan ini dilakukan untuk menyingkirkan dampak personal dan melindungi kejadian sosial di tempat penelitian dapat terjadi sealamiah mungkin dan seperti mana harusnya. Dalam penelitian ini, peneliti akan hadir melakukan penelitian selama 4 bulan yaitu dimulai bulan Februari 2021 sampai dengan Mei 2021.

Tahap exploration, peneliti akan mengexplore atau mencari tahu atau melakukan survei awal terhadap keberadaan lokasi tempat penelitian yaitu rumah tahsin alQur'an desa gegutu kacang. Tahap ini peneliti sedang peneliti lakukan sebagai langkah awal ketika penyusunan proposal penelitian. Sedangkan pada tahap cooperation, peneliti akan menjalin kerjasama atau hubungan baik dan membangun keakraban dengan pihak-pihak rumah tahsin tersebut yang terpaut sebagai responden atau informan pada penelitian penerapan metode Asy-Syafi'i dalam pembelajaran AlQur'an. Terakhir pada tahap participation, peneliti akan mengadakan partisipasi atau keikutsertaan terhadap fokus penelitian pada penelitian ini yaitu berupa keikut sertaan peneliti dalam pelaksanaan pembelajaran al-Qur'an metode Asy-Syafi'i yang sesuai dengan jadwal. Di rumah tahsin desa gegutu kacang, peneliti mengadakan partisipasi atau keikutsertaan pelaksanaan pembelajaran al-Qur'an metode Asy-Syafi'i pada kelompok pemula atau tingkat dasar.

\section{Teknik Pengumpulan Data}

Pada penelitian ini, peneliti menggunakan beberapa teknik dalam mengumpulkan data yaitu teknik wawancara, teknik observasi dan teknik dokumentasi. Ketiga teknik tersebut akan penulis jelaskan di bawah ini:

a) Observasi (Pengamatan), Observasi merupakan suatu prosedur mengumpulkan data dengan mengadakan pengamatan terhadap kegiatan yang sedang berlangsung dan mencatat hasil pengamatan secara sistematis di lapangan Sukmadinata (2016). Dan jenis observasi yang digunakan dalam penelitian ini adalah jenis observasi partisipan yaitu pengumpulan data melalui pengamatan terhadap objek pengamatan dengan langsung hidup bersama, merasakan serta berada dalam aktivitas kehidupan objek pengamatan Bungin (2011). Maka dalam penelitian ini, peneliti akan mengamati dan mengikuti pelaksanaan pembelajaran alQur'an metode Asy-Syafi'i secara bersama-sama dari awal sampai akhir pembelajaran. Peneliti juga akan berusaha mengamati, menganalisis dan menyimpulkan maksud dari setiap tingkah laku dan perasaan yang terlihat oleh peneliti pada guru Asy-Syafi'i dan Peserta didik dalam pembelajaran al-Qur'an metode asy-Syafi'i tersebut. Selain itu, peneliti juga akan mengadakan observasi terseleksi terhadap beberapa Peserta didik yang dipilih secara acak berdasarkan tingkatan materi Asy-Syafi'i. Observasi terseleksi ini dilakukan untuk mengetahui tingkat atau prosentase dampak penerapan metode asy-Syafi'i terhadap kemampuan membaca al-Qur'an peserta didik.

b) Teknik Wawancara (Interview), Wawancara adalah cara menghimpun bahan keterangan yang dilaksanakan dengan mengadakan tanya jawab lisan secara sepihak, berhadapan muka, dan dengan arah serta tujuan yang telah ditentukan. Jenis metode wawancara yang digunakan dalam penelitian ini adalah metode wawancara secara mendalam dan terstruktur. Maka peneliti akan menggunakan pedoman wawancara (interview guide) dalam melakukan wawancara. Adapun pihak-pihak yang akan diwawancarai oleh peneliti adalah koordinator Asy-Syafi'i dan guru Asy-Syafi'i di Mushallah Ahsanul Qolbu Perumahan Griya Sehati Terongtawah Kec. Labuapi. Peneliti menggunakan metode wawancara ini untuk mendapatkan informasi tentang langkah-langkah guru dalam perencanaan pembelajaran alQuran metode Asy-Syafi'i, strategi dalam pembelajaran al-Quran dengan metode t Asy-Syafi'i, teknik guru dalam evaluasi pembelajaran al-Quran metode Asy-Syafi'i dan dampak penerapan metode Asy-Syafi'i terhadap kemampuan membaca al-Qur'an peserta didik. Wawancara akan difokuskan pada entri point: (1) Bagaimana Proses Penyampaian Metode Pembelajaran Al-Qur'an Kepada Peserta Didik (2) Apa Saja Isi Materi Yang Disampaikan Dalam Metode Pembelajaran al-Qur'an di Mushallah Ahsanul Qolbu.

c) Teknik Dokumentasi, Metode dokumentasi adalah suatu metode atau cara pengambilan data yang diperoleh di tempat penyimpanan dokumen. Dalam melaksanakan metode ini peneliti menyelidiki benda-benda, data yang tidak mungkin diperoleh dengan menggunakan interview dan observasi Sugiyono (2017). Dokumentasi akan difokuskan pada entri point: (1) Bagaimana proses penyampaian metode pembelajaran al-Qur'an kepada peserta didik (2) Apa aaja isi materi yang disampaikan dalam metode pembelajaran alQur'an di rumah tahsin. Studi dokumentasi yang peneliti lakukan adalah terutama pada dokumen resmi rumah tahsin. Dokumentasi ini peneliti jadikan landasan tentang keberadaan pembelajaran yang memiliki basis pendidikan Multikultural. Dokumentasi yang dikumpulkan juga peneliti manfaatkan untuk crosscheck data dari hasil pengamatan dan wawancara.

\section{Metode Analisis Data}

Data dalam penelitian kualitatif terbagi menjadi dua bentuk yaitu pertama, data yang diperoleh dalam bentuk katakata atau ucapan lisan (verbal) dan perilaku dari subjek (informan). Bentuk data yang pertama dalam penelitian ini adalah segala bentuk hasil wawancara dan observasi peneliti terhadap informan yang berkaitan dengan penerapan metode Asy-Syafi'i dan dampaknya terhadap kemampuan membaca al-Qur'an peserta didik. Kedua, data yang berasal dari dokumen-dokumen, foto-foto, dan benda-benda yang dapat digunakan sebagai pelengkap. Bentuk data yang kedua dalam penelitian ini adalah segala bentuk dokumen, foto dan benda yang diperoleh peneliti dari informan dan berkaitan dengan penerapan metode Asy-Syafi'i dalam pembelajaran alQur'an.

Sumber data dalam penelitian ini adalah pertama, sumber data primer yang mencakup manusia sebagai subjek atau informan penelitian. Sumber data primer dalam penelitian ini adalah koordinator Asy-Syafi'i, guru Asy-Syafi'i dan peserta didik di Ahsanul Qolbu. Peneliti akan memilih guru AsySyafi'i menjadi informan kunci karena guru Asy-Syafi'i merupakan perencana, pelaksana dan pengevaluasi hasil dari proses pembelajaran al-Qur'an metode Asy-Syafi'i. Kedua, sumber data sekunder yang berasal bukan dari manusia. Sumber data sekunder dalam penelitian ini adalah dokumendokumen yang relevan dengan fokus penelitian dan bersifat hard data (data keras), seperti gambar, foto dan catatan yang terkait dengan penerapan metode Asy-Syafi'i dalam 
pembelajaran al-Qur'an. Dalam penelitian kualitatif terdapat juga objek penelitian. Objek penelitian adalah sasaran atau titik perhatian suatu penelitian. Adapun yang menjadi objek penelitian dalam penelitian ini adalah pertama, langkahlangkah guru dalam perencanaan pembelajaran al-Qur'an metode Asy-Syafi'i. Kedua, proses guru dalam pelaksanaan pembelajaran al-Qur'an metode Asy-Syafi'i. Ketiga, teknik guru dalam evaluasi pembelajaran Al-Qur'an metode AsySyafi'i. Dan yang keempat, dampak penerapan metode AsySyafi'i terhadap kemampuan membaca al-Qur'an Peserta didik

\section{HASIL DAN PEMBAHASAN}

\section{Perencanaan Pembelajaran Al-Qur'an Metode Asy- Syafi'i}

Sebelum melaksanakan proses pembelajaran, guru harus menyusun perencanaan pembelajaran. Dalam perencanaan, guru akan menetapkan apa yang harus dilakukan dalam pembelajaran. Hal ini sebagaimana yang dijelaskan oleh Terry, bahwa perencanaan yaitu penetapan pekerjaan yang harus dilaksanakan oleh kelompok untuk mencapai tujuan yang telah ditentukan. Perencanaan merupakan kegiatan untuk menetapkan pekerjaan yang harus dilaksanakan dalam suatu kelompok demi meraih tujuan yang telah diputuskan. Begitu juga dengan perencanaan yang dilaksanakan dalam kelompok belajar al-Qur'an metode Asy-Syafi'i, guru AsySyafi'i harus menetapkan kegiatan-kegiatan atau ketentuanketentuan yang akan dilakukan untuk mencapai tujuan pembelajaran al-Qur'an metode Asy-Syafi'i. Dengan ditetapkannya perencanaan dalam pembelajaran, semua kegiatan yang akan dilaksanakan dalam proses pembelajaran dapat tersusun dan terlaksana dengan baik, matang, terukur serta tidak diluar batas kendali guru. Karena perencanaan tersebut merupakan acuan guru dalam melaksanakan kegiatan dalam proses pembelajaran.

Adapun menurut William H. Newman dalam Abdul Majid, menjelaskan bahwa: Perencanaan adalah menentukan apa yang dilakukan. Perencanaan mengandung rangkaianrangkaian putusan yang luas dan penjelasan-penjelasan dari tujuan, penentuan kebijakan, penentuan program, penentuan metode- metode dan prosedur tertentu dan penentuan kegiatan berdasarkan jadwal sehari-hari. Perencanaan sebagai suatu langkah untuk menentukan apa yang akan dilakukan, terdiri dari rangkaian kegiatan penentuan kebijakan, penentuan program, penentuan metode dan penentuan prosedur suatu pekerjaan yang akan dilakukan. Jadi rangkaian-rangkaian kegiatan tersebut dirancang dan diputuskan menjadi suatu format atau bentuk perencanaan. Demikian juga halnya dengan langkah-langkah perencanaan yang dilakukan guru Asy-Syafi'i dalam pembelajaran AlQur'an dengan metode Asy-Syafi'i di Mushallah Ahsanul Qolbu Perumahan Griya Sehati, yaitu terdiri dari kegiatan menentukan desain posisi pembelajaran, menentukan durasi pembelajaran, menentukan jumlah Peserta didik dalam kelompok, menentukan model pembelajaran yang akan diterapkan dalam pembelajaran Al-Qur'an metode AsySyafi'i.

Beberapa langkah perencanaan guru dalam ruang kelas adalah: 1) Pengaturan tempat duduk yaitu posisi berhadapan, posisi setengah lingkaran dan posisi berbaris ke belakang; 2) Pengaturan alat-alat pengajaran terdiri dari perpustakaan kelas, alat peraga/media pembelajaran, papan tulis, kapur tulis dan papan presensi peserta didik; 3) Penataan keindahan dan kebersihan kelas terdiri dari hiasan dinding, penempatan lemari dan pemeliharaan kebersihan serta; 4) Ventilasi dan tata cahaya. Hal diatas sebagaimana yang dilakukan guru Asy-Syafi'i dalam perencanaan pembelajaran Al-Qur'an dengan metode Asy-Syafi'i di Mushallah Ahsanul Qolbu Perumahan Griya Sehati, terdapat kegiatan menentukan desain posisi pembelajaran atau pengaturan tempat duduk guru dan Peserta didik. Bentuk pengaturan tempat duduk guru dan Peserta didik yang diterapkan di rumah tahsin ini adalah bentuk leter O. Dan pengaturan posisi alat-alat pengajaran seperti alat peraga Asy-Syafi'i berada tepat di belakang guru. Kedua pengaturan tersebut telah dirancang dan ditetapkan sebagaimana pilihan desain posisi pembelajaran yang direkomendasikan oleh metode Asy-Syafi'i.

Beberapa hal-hal yang perlu diperhatikan guru dalam pengaturan ruang belajar yang termasuk langkah perencanaan pembelajaran yaitu: 1) Ukuran dan bentuk kelas; 2) Bentuk serta ukuran bangku dan meja peserta didik; 3) Jumlah peserta didik dalam kelas; 4) Jumlah peserta didik dalam setiap kelompok; 5) Jumlah kelompok dalam kelas dan 6) Komposisi peserta didik dalam kelompok (seperti peserta didik pandai dengan peserta didik kurang pandai, pria dengan wanita). Begitu juga halnya dengan langkah-langkah yang direncanakan guru Asy-Syafi'i dalam pembelajaran Al Qur'an di Mushallah Ahsanul Qolbu Perumahan Griya Sehati yaitu menentukan jumlah peserta didik dalam 1 kelompok yaitu sebanyak 3-10 orang dewasa. Kemudian model pengelolaan kelas yang digunakan oleh peserta didik dalam pembelajaran Al Qur'an dalam metode Asy-Syafi'i di adalah model sorogan dengan penyesuaian ukuran ruang kelas.

\section{Proses Pelaksanaan Pembelajaran Al-Qur'an Metode Asy-Syafi'i}

Proses yang dilakukan secara sadar dan memiliki tujuan. Tujuan adalah sebagai pedoman ke arah mana akan dibawa proses belajar mengajar. Proses belajar mengajar akan berhasil bila hasilnya mampu membawa perubahan dalam pengetahuan, pemahaman, keterampilan dan nilai-sikap dalam diri peserta didik. Begitu juga halnya dengan pembelajaran Al-Qur'an metode Asy-Syafi'i yang dilaksanakan, memiliki tujuan agar Peserta didik dapat membaca Al-Qur'an dengan baik dan benar dari bidang fashohah, makharijul huruf, tajwid, gharib dan lagu tartil yang telah ditetapkan pada metode Asy-Syafi'i. Sebelum melaksanakan proses pembelajaran, guru perlu melakukan kegiatan mengelola kelas. Kegiatan mengelola kelas tersebut memiliki tujuan sebagaimana yang dikatakan oleh Zuldafrial adalah: 1) Mewujudkan situasi dan kondisi kelas yang memungkinkan peserta didik mengembangkan kemampuan secara optimal; 2) Mempertahankan keadaan yang stabil dalam suasana kelas, sehingga bila terjadi gangguan dalam belajar mengajar dapat dieliminir; 3) Menghilangkan berbagai hambatan dan pelanggaran yang dapat merintangi terwujudnya interaksi belajar mengajar; 4) Mengatur semua 
perlengkapan dan peralatan yang memungkinkan peserta didik belajar sesuai dengan lingkungan sosial, emosional dan intelektual peserta didik dalam kelas; 5) Melayani dan membimbing perbedaan individual peserta didik.

\section{[Figure 2 about here.]}

Adapun kegiatan mengelola kelas yang dilakukan guru Asy-Syafi'i dalam proses pembelajaran Al-Qur'an metode Asy-Syafi'i di Mushallah Ahsanul Qolbu Perumahan Griya Sehati, berdasarkan subtansi pembahasan yang sedang dipelajari Peserta didik dan menggabungkan kelompok yang berdekatan. Sedangkan kegiatan mengelola kelas yang dilakukan dalam proses pembelajaran Al-Qur'an metode Asy-Syafi'i di Mushallah Ahsanul, sesuai dengan pencapaian Peserta didik pada masing-masing subtansi pembahsan materi dan pembagiannya secara random atau acak. Tetapi khusus untuk Peserta didik kelas dasar atau pemula, pengelompokkannya berdasarkan hasil placement test. Dalam melaksanakan proses pembelajaran terdapat kegiatan awal, kegiatan inti dan kegiatan penutup. Kegiatan awal yang dilaksanakan guru dalam proses pembelajaran adalah membuka pelajaran dan melakukan apersepsi. Dalam melaksanakan kegiatan membuka pelajaran, guru harus memiliki keterampilan dalam melakukannya. Demikian juga yang diungkapkan oleh Syaiful Bahri Djamarah, keterampilan membuka pelajaran adalah perbuatan guru untuk menciptakan siap mental dan menimbulkan perhatian anak didik agar terpusat pada apa yang akan dipelajari. Siasat membuka pelajaran bertujuan untuk menyiapkan mental peserta didik agar siap memasuki persoalan yang akan dipelajari atau dibicarakan, menimbulkan minat serta pemusatan anak didik pada apa yang akan dibicarakan dalam kegiatan interaksi edukatif.

Adapun kegiatan membuka pelajaran yang dilakukan guru Asy-Syafi'i dalam proses pembelajaran Al Qur'an Metode Asy-Syafi'i yaitu mengucapkan salam pembuka dan membaca do "ea sebelum belajar al-Qur'an secara bersamasama. Do"e y yang akan dibaca sudah tertulis dalam modul mengajar guru Asy-Syafi'i. Kemudian guru akan melakukan apersepsi yaitu membaca ulang materi yang dipelajari kemarin secara bersama-sama. Dalam proses pelaksanaan pembelajaran disarankan adanya penggunaan media pembelajaran. Media pembelajaran ini dapat berupa media cetak ataupun non cetak. Intinya media pembelajaran yang digunakan tersebut merupakan alat peraga yang dapat dilihat, disentuh dan dirasa oleh Peserta didik. Fungsi penggunaan media dalam pembelajaran adalah hal-hal bersifat abstrak bisa dikongkritkan dan hal-hal yang terlalu besar bisa dikecilkan dan sebaliknya. Dan menurut Arsyad, semakin banyak alat indra yang digunakan untuk menerima dan mengolah informasi, maka semakin banyak materi pelajaran yang dapat dimengerti dan dipertahankan dalam ingatan.

\section{[Figure 3 about here.]}

Berkaitan dengan pernyataan diatas, guru Asy-Syafi'i di rumah tahsin juga menggunakan media pembelajaran dalam proses pelaksanaan pembelajaran Al Qur'an Metode Asy-
Syafi'i, jika media pembelajaran belum selesai dibaca bersama-sama. Cara guru menggunakan media pembelajaran adalah dengan membaca materi pada alat peraga Asy-Syafi'i dan diikuti seluruh murid. Setelah itu guru menunjuk murid satu per satu untuk membaca materi pada alat peraga dan disimak oleh murid yang lain (jika waktunya memadai). Alat peraga yang digunakan guru dalam pembelajaran $\mathrm{Al}$ Qur'an Metode Asy-Syafi'i yaitu berupa kumpulan materi pada buku ajar Asy-Syafi'i brupa buku khusus untuk memperagakan metode Asy-Syafi'i.

\section{Teknik Guru Dalam Evaluasi Pembelajaran Al- Qur'an Metode Asy-Syafi'i}

Dalam proses pembelajaran perlu dilaksanakan evaluasi atau tes atau ujian hasil belajar. Evaluasi ini dilaksanakan gunanya untuk mengetahui batas pemahaman atau kemampuan Peserta didik terhadap suatu materi pelajaran. Hal ini senada dengan yang diungkapkan oleh Mulyadi, bahwa manfaat hasil ujian bagi peserta didik adalah: 1) Dapat mengetahui apakah ia sudah mengetahui bahan yang disajikan oleh guru; 2) Dapat mengetahui bagian mana yang belum dikuasainya sehingga ia berusaha untuk mempelajarinya sebagai upaya perbaikan; 3) Dapat merupakan penguatan bagi murid yang sudah memperoleh skor tinggi; 4) Dapat merupakan diagnosa bagi murid yang bersangkutan ia mengetahui bagian yang sukar untuk dikuasainya. Begitu juga halnya dengan evaluasi yang dilaksanakan guru Asy-Syafi'i dalam pembelajaran AlQur'an Metode Asy-Syafi'i di rumah tahsin memiliki tujuan untuk mengetahui apakah Peserta didik sudah dapat memahami materi yang diajarkan guru. Dan hasil evaluasi tersebut akan menjadi sebab guru untuk meminta Peserta didik melanjutkan atau mengulangi bacaannya pada halaman buku panduan yang dipelajari.

Evaluasi dapat dilaksanakan langsung setiap akhir pembelajaran atau setiap kurun waktu tertentu dalam proses pembelajaran. Hal ini senada dengan yang diungkapkan Suharsimi Arikunto, bahwa evaluasi yang dilaksanakan dalam proses pembelajaran terdiri dari 3 bentuk evaluasi yaitu sebagai berikut: 1) Tes formatif adalah penilaian yang digunakan untuk mengukur satu atau beberapa pokok bahasan tertentu dan bertujuan untuk memperoleh gambaran tentang daya serap Peserta didik terhadap pokok bahasan tersebut. 2) Tes subsumatif adalah penilaian yang meliputi sejumlah bahan pengajaran dalam waktu tertentu; 3) Tes sumatif adalah penilaian yang diadakan untuk mengukur daya serap Peserta didik terhadap bahan pokok-pokok bahasan yang telah diajarkan selama satu semester, satu atau dua tahun pelajaran.

Demikian juga halnya dengan evaluasi yang dilaksanakan guru Asy-Syafi'i dalam pembelajaran Al-Qur'an Metode Asy-Syafi'i di Mushallah Ahsanul Qolbu Perumahan Griya Sehati terdiri dari 3 bentuk evaluasi yaitu sebagai berikut: 1) Evaluasi yang dilaksanakan guru tsqifa kepada Peserta didik ketika akhir pertemuan dalam pembelajaran Al-Qur'an Metode Asy-Syafi'i. Evaluasi ini dilaksanakan dengan tujuan untuk melihat kemampuan Peserta didik bisa naik atau tidak ke halaman selanjutnya pada jilid buku Asy-Syafi'i yang dipelajarinya; 2) Hasil yang diperoleh Peserta didik dalam evaluasi ini akan ditulis di buku prestasi Asy-Syafi'i Peserta 
didik dan jurnal. Sebagaimana yang diketahui bahwa jurnal merupakan catatan pendidik di dalam dan di luar kelas yang berisi informasi hasil pengamatan tentang kekuatan dan kelemahan peserta didik yang berkaitan dengan sikap dan perilaku. Hal diatas sesuai dengan apa yang dilakukan guru Asy-Syafi'i dalam evaluasi pembelajaran Al-Qur'an metode Asy-Syafi'i di Mushallah Ahsanul Qolbu Perumahan Griya Sehati, bahwa hasil evaluasi Peserta didik setiap akhir pertemuan dalam pembelajaran Al-Qur'an metode AsySyafi'i akan ditulis di buku prestasi Asy-Syafi'i Peserta didik dan jurnal mengajar yang diberikan koordinator Asy-Syafi'i setiap bulan; 3) Evaluasi yang dilaksanakan guru Asy-Syafi'i kepada Peserta didik ketika akan naik pembahasan yang sedang dipelajarinya. Evaluasi ini dilaksanakan dengan tujuan untuk melihat kemampuan Peserta didik bisa naik atau tidak ke pebahasa berikutnya selanjutnya; 4) Evaluasi yang dilaksanakan oleh koordinator Asy-Syafi'i kabupaten atau kota setempat kepada peserta didik ketika akhir seluruh pembelajaran Al-Qur'an metode Asy-Syafi'i. Evaluasi ini dilaksanakan dengan tujuan untuk menentukan kelulusan peserta didik dalam pembelajaran Al-Qur'an dengan metode Asy-Syafi'i. Dalam evaluasi akhir ini terdapat 2 bentuk evaluasi yaitu: a) Munaqasyah. Bahan yang akan diujikan dalam evaluasi munaqasyah ini adalah: 1.) Fashahah dan tartil Al-Qur'an (juz 1-30); 2.) Membaca gharib dan penjelasannya; 3.) Teori ilmu tajwid dan menguraikan hukum-hukum bacaan

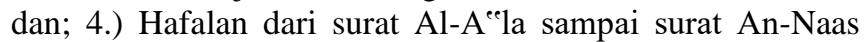
metode Asy-Syafi'i. b) Khataman dan imtihan, Khataman dan imtihan merupakan bentuk evaluasi yang melibatkan publik. Kegiatan ini melibatkan seluruh stakeholder sekaligus merupakan laporan secara langsung kualitas hasil pembelajaran Al-Qur'an Metode Asy-Syafi'i kepada orang tua wali santri/masyarakat. Kegiatan evaluasi ini meliputi: 2.) Uji publik kemampuan membaca, hafalan, bacaan gharib dan tajwid dasar serta; 3.) Uji dari tenaga ahli al-Qur'an dari tim Asy-Syafi'i dengan lingkup materi tertentu.

\section{Dampak Penerapan Metode Asy-Syafi'i Terhadap Kemampuan Membaca Al-Qur'an Peserta didik}

Suatu kegiatan pembelajaran dikatakan berhasil jika dapat terlaksana dan tercapai seluruh tujuan pembelajaran dengan baik. Dan dikatakan juga bahwa suatu proses pembelajaran dikatakan berhasil, apabila memiliki dampak atau perubahan yang penting dan terlihat dalam diri peserta didik setelah proses pembelajaran tersebut. Dampak atau perubahan setelah proses pembelajaran tersebut dapat dilihat dari tolak ukur atau parameter yang dirumuskan dalam pembelajaran. Dan yang menjadi tolak ukur keberhasilan suatu proses pembelajaran adalah: 1) Daya serap terhadap bahan pembelajaran yang diajarkan mencapai prestasi tinggi, baik secara individual maupun kelompok; 2) Perilaku yang digariskan dalam tujuan pembelajaran telah dicapai oleh Peserta didik, baik secara individual maupun kelompok.

Sebagaimana juga dampak penerapan metode Asy-Syafi'i yang terlihat di tahsin al-qur'an mushallah ahsanul qolbu adalah: 1) Daya serap Peserta didik terhadap materi pelajaran al-Qur'an metode Asy-Syafi'i adalah cepat.; 2) Perilaku yang digariskan dalam tujuan pembelajaran yaitu Peserta didik menjadi lebih memahami cara mengucapkan huruf hijaiyah sesuai dengan makharijul huruf, tajwid, gharib serta lagu
Peserta didik dalam membaca al-Qur'an menjadi lebih tertata.

\section{KESIMPULAN}

Berdasarkan paparan data, hasil penelitian dan pembahasan hasil penelitian pada bab-bab sebelumnya. Maka simpulan dari penelitian ini adalah sebagai berikut: 1). Langkahlangkah guru dalam perencanaan pembelajaran al-Qur'an metode Asy-Syafi'i berpedoman pada aturan-aturan yang telah ditetapkan oleh guru Asy-Syafi'i seperti menentukan durasi pembelajaran dan desain posisi pembelajaran. Maka dapat dikatakan bahwa ketentuan-ketentuan yang telah disusun guru Asy-Syafi'i dalam perencanaan pembelajaran, tidak terlepas dari ketentuan baku metode Asy-Syafi'i. Tahapan pembelajaran tersebut terdiri dari beberapa bagian yaitu pembukaan, apersepsi, penanaman konsep, pemahaman konsep, latihan/keterampilan kemandirian, evaluasi dan penutup. 2).Teknik guru dalam evaluasi pembelajaran al-Qur'an metode Asy-Syafi'i mengacu kepada teknik evaluasi yang telah ditetapkan dala buku metode Asy-Syafi'i sangat berdampak baik terhadap kemampuan membaca alQur'an peserta didik. Hal ini dapat dilihat dari daya serap dan perilaku pese rta didik yang tampak setelah pelaksanaan proses pembelajaran al-Qur'an.

\section{UCAPAN TERIMA KASIH}

Tak lupa kami ucapkan terimakasih kepada rekan-rekan di Universitas Muhammadiyah Mataram yang selalu memberikan dukungan sehingga kami dapat menyelesaikan artikel ini 


\section{REFERENCES}

Alamsyah. (2015). ilmu-ilmu hadits (Ǔlūm al-Hadīś). CV. Anugrah Utama Raharja (AURA).

Bungin, B. (2011). Komunikasi,Ekonomi,Kebijakan Publik,dan Ilmu Sosial Lainnya. Kencana Prenada Media Group.

Creswell, J. W. (2010). Pendekatan Kualitatif, Kuantitatif dan Mixed (3rd ed.). Pustaka Pelajar.

Darwin. (2018). Pengaruh Penguasaan Ilmu Tajwid dan Tahsin Terhadap hasil belajar Al-quran (Studi Kasus Pada Siswa Madrasah Aliyah Negri 1 Kendari Sulawesi Tenggara). Fikratuna, 9, 82-91.

Ishaq, A. H., \& Nawawi, R. (2017). Ilmu Tajwid Dan Implikasinya Terhadap Ilmu Qira'Ah. Qof, 1(1), 15-24. https://doi.org/10.30762/qof.v1i1.926

Mappanyompa, M. M., \& Mustapa Ali, M. A. M. A. (2017). Urgensi Penggunaan Multimedia Interaktif Terhadap Peningkatan Motivasi Belajar Siswa Dalam Pembelajaran Bahasa Arab Kelas Va Min Malang 2. Ibtida'iy : Jurnal Prodi PGMI, 2(2), 54. https://doi.org/10.31764/ibtidaiy.v2i2.1049

Mubarak, H. (2013). Upaya Guru Al-Qur'an Dalam Mengatasi Kesulitan Belajar Membaca Al-Qur'an Di Sdit Ukhuwah Banjarmasin. Jurnal Studia Insania, 1(1), 39. https://doi.org/10.18592/jsi.vli1.1078

Mulyani, D., Pamungkas, I., \& Inten, D. N. (2018). Al-Quran Literacy for Early Childhood with Storytelling Techniques. Jurnal Obsesi : Jurnal Pendidikan Anak Usia Dini, 2(2), 202. https://doi.org/10.31004/obsesi.v2i2.72

Nazir, M. (2014). Metode Penelitian. Penerbit Ghalia Indonesia.

Prastowo, A. (2011). No image available for this title Metode Penelitian Kualitatif (M. Sandra (ed.)). Ar-Ruzz Media.

Purba, A. (2019). Mendidik Anak dalam Mencintai al- Qur' an ... Mendidik Anak dalam Mencintai al- Qur' an .... 08(02), 347-368.

Rahmi, E. (2019). Buku Modul Metodologi Pengajaran Al-Quran Hadis. Deepublish.

Satria, E., Tresnawati, D., \& Nurvitrya, A. (2015). Pengembangan Aplikasi Pembelajaran Iqra' dan Tajwid Berdasarkan Metode Asy-Syafi'i
Menggunakan Sistem Multimedia. Jurnal Algoritma, 12(1), 74-81. https://doi.org/10.33364/algoritma/v.12-1.74

Shihab, Q. (2011). Membumikan Al-Qur'an (2nd ed.). Penerbit Lentera Hati.

Sugiyono. (2017). Metode Penelitian Kuantitatif Kualitatif dan R\&D. Penerbit Alfabeta.

Sukmadinata, N. S. (2016). Metode penelitian pendidikan (11th ed.).

Usman, A., \& Ansyari, H. (2016). Pelatihan Metode membaca Al- Qur'an Berbasis Qiraah Asy- Syafi'i bagi Mahasiswa FIK UNM. Prosiding Seminar Nasional, 408-412.

Conflict of Interest Statement: The authors declare that the research was conducted in the absence of any commercial or financial relationships that could be construed as a potential conflict of interest.

Copyright (C) 2021 Mappanyompa, Hidyatussaliki. This is an open-access article distributed under the terms of the Creative Commons Attribution License (CC BY). The use, distribution or reproduction in other forums is permitted, provided the original author(s) and the copyrightowner(s) are credited and that the original publication in this journal is cited, in accordance with accepted academic practice. No use, distribution or reproduction is permitted which does not comply with these terms. 


\section{LIST OF FIGURES}

1 Tahapan Metodologi Penelitian Penerapan Metode Asy-Syafi'i ….............................................................. 128

2 Proses Pembelajaran Tahsin Metode Asy-Syafi'i

129

3 Media Pembelajaran Tahsin Buku Metode Asy-Syafi'i 


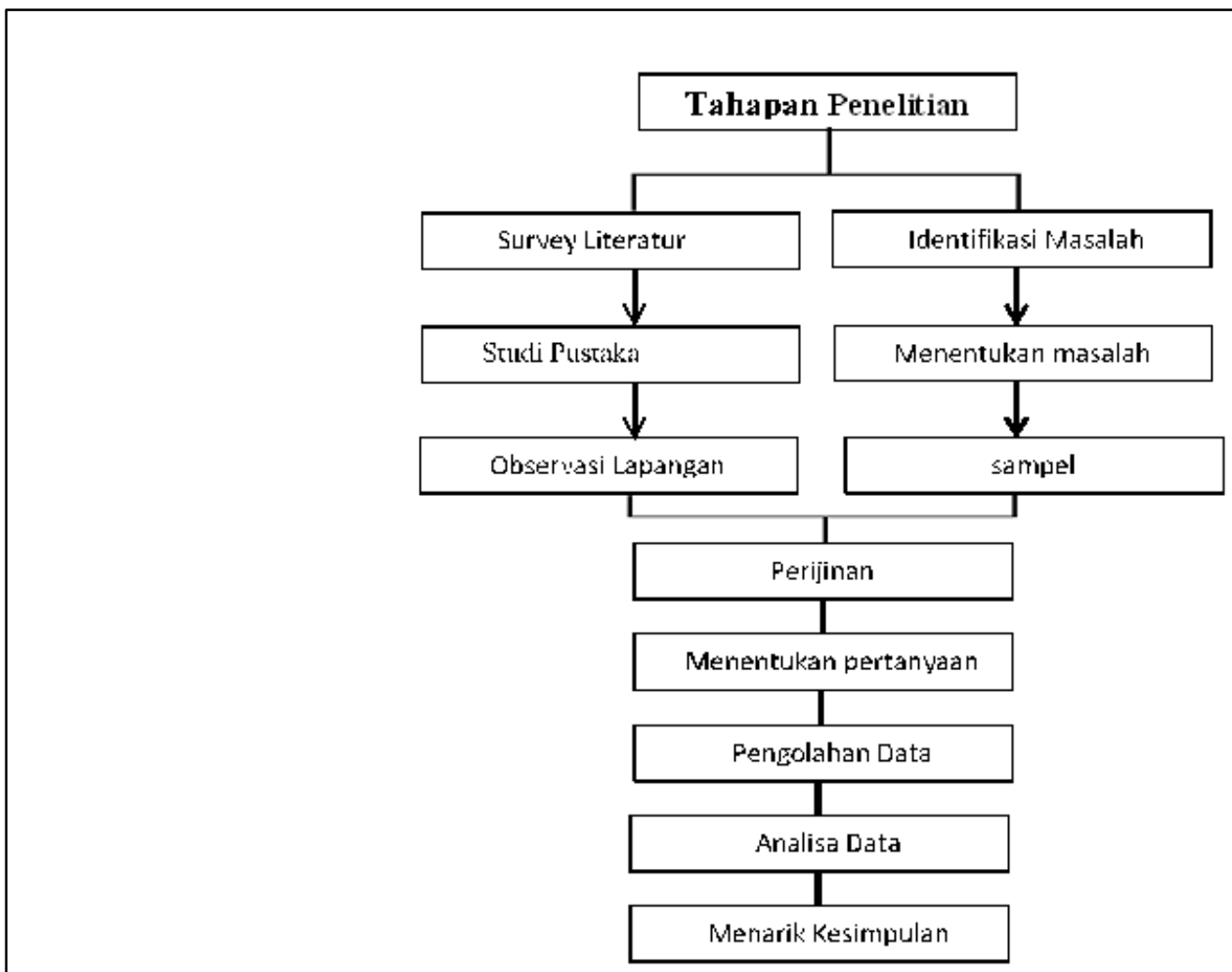

FIGURE 1 / Tahapan Metodologi Penelitian Penerapan Metode Asy-Syafi'i 


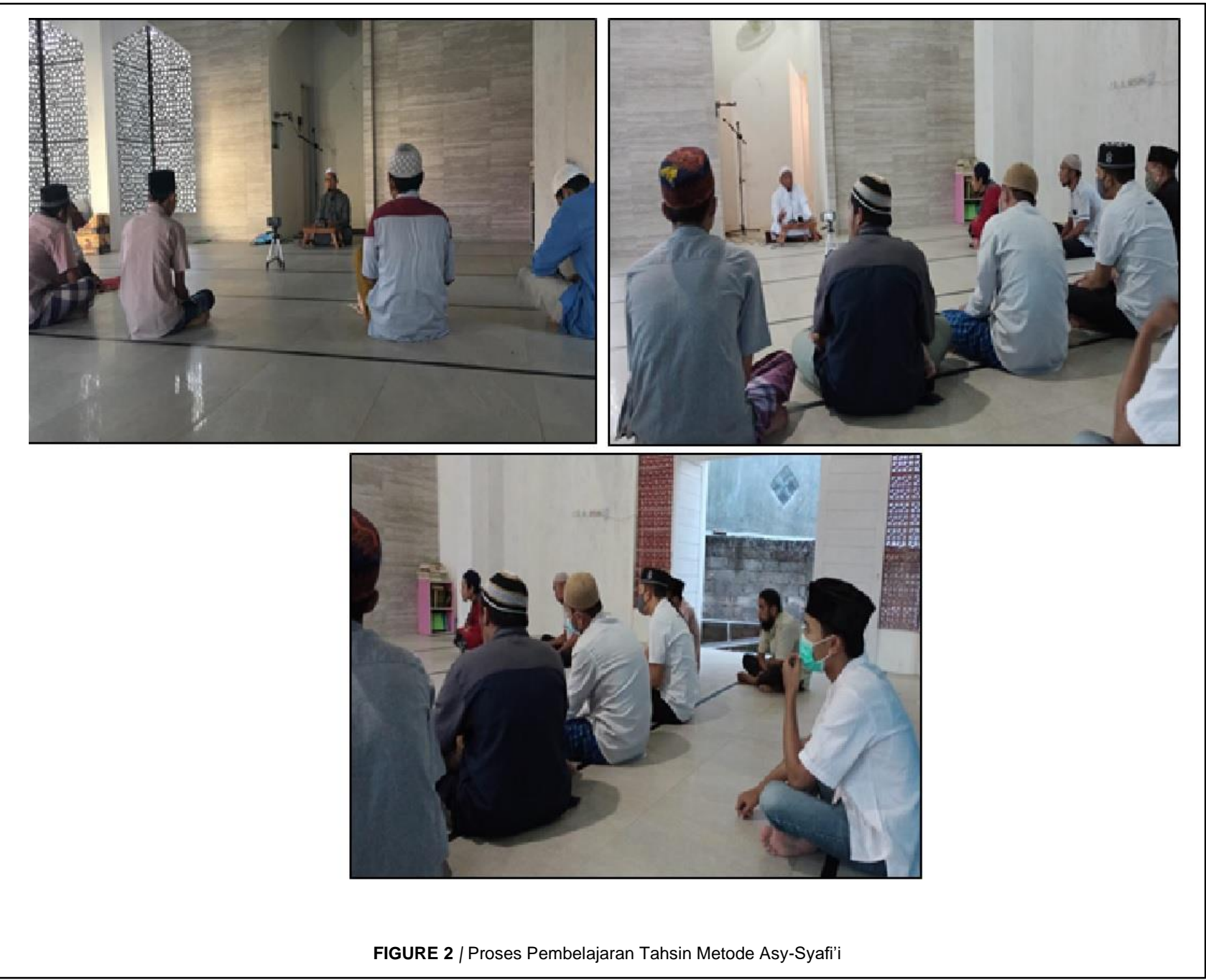




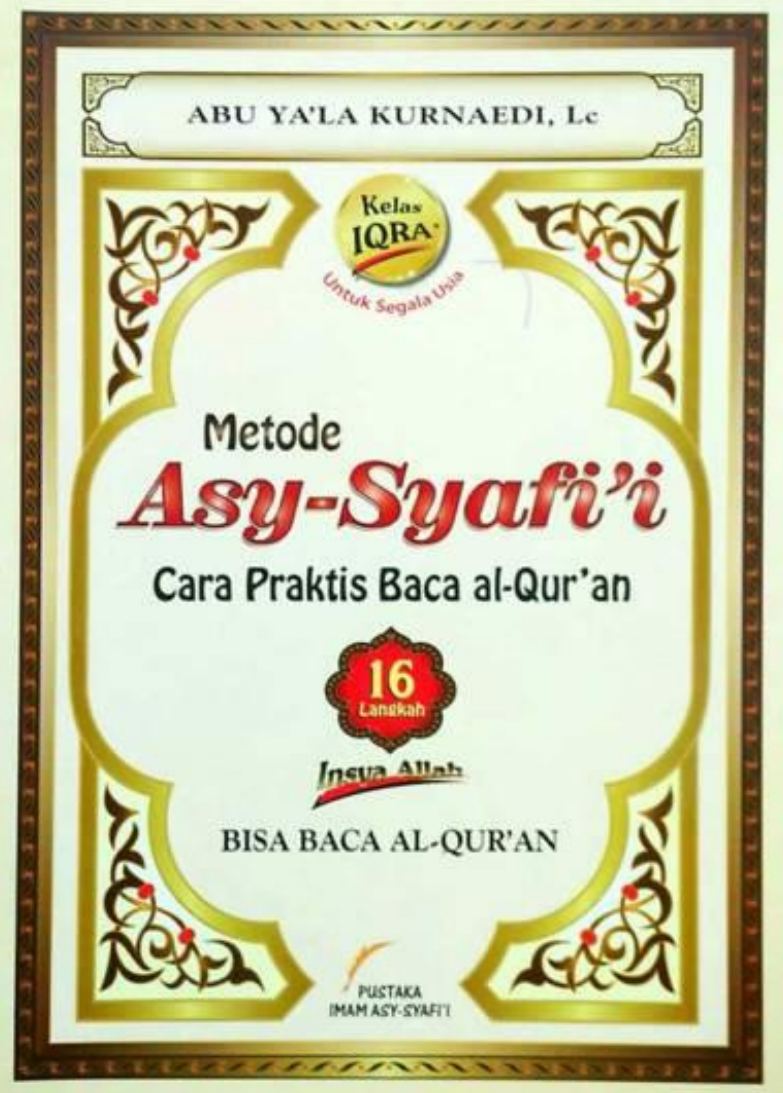

FIGURE 3 / Media Pembelajaran Tahsin Buku Metode Asy-Syafi'i 